\title{
Tungku Tigo Sajarangan, Tali Tigo Sapilin: A Strategy Towards World Class University Based on Local Wisdom Perspective
}

\author{
Andi Amri 1, Zulmi Ramdani 2, Jaka Warsihna 3, Lidwina Felisima Tae 4 \\ DOI: $10.35445 /$ alishlah.v13i1.386
}

\begin{abstract}
Article Info
Abstract

Keywords:

Educational Principle

Educational Success

Local Wisdom

Minangkabau Culture

World Class University

This study aims to analyze and describe Tungku Tigo Sajarangan, Tali Tigo Sapilin as an indicator to achieve a world-class university. Descriptive qualitative research methods were used to answer this objective by conducting several procedures such as interviews with the cultural expert of Minangkabau, interviews with the educational experts, direct observation of learning activities in the university, and study the scientific literature. Thematic content analysis was used to find informative descriptions of the data obtained. The results showed that the concept of leadership, customs, and local wisdom originating from Minangkabau culture could become an alternative framework and a formula for the realm of education especially for the universities to become a world-class university. The steps for implementing Tungku Tigo Sajarangan, Tali Tigo Sapilin include four stages namely preparation, implementation, postimplementation, and evaluation.
\end{abstract}

Kata kunci:

Budaya Minangkabau

Kesuksesan Pendidikan

Kearifan Lokal

Prinsip Pendidikan

Universitas Kelas Dunia

\begin{abstract}
Abstrak
Penelitian ini bertujuan untuk menganalisis dan menjelaskan konsep Tungku Tigo Sajarangan, Tali Tigo Sapilin sebagai indikator dalam mencapai universitas berkelas dunia. Metode penelitian kualitatif deskriptif digunakan untuk menjawab tujuan tersebut dengan melakukan beberapa prosedur seperti melakukan wawancara dengan ahli budaya Minangkabau, wawancara dengan ahli pendidikan, observasi langsung pada aktivitas pembelajaran di kampus dan mempelajari literature ilmiah. Penelitian ini menggunakan analisis konten tematik untuk mendapatkan informasi dari deskripsi yang diperoleh. Hasil penelitian menunjukkan bahwa konsep kepemimpinan, adat istiadat dan kearifan lokal yang berasal dari budaya Minangkabau bisa menjadi kerangka berpikir alternatif dan cara yang cocok dalam bidang pendidikan, salah satunya bagi sebuah universitas untuk menjadi universitas kelas dunia. Tahapan dalam mengimplementasikan konsep Tungku Tigo Sajarangan, Tali Tigo Sapilin terdiri dari empat tahap meliputi persiapan, implementasi, pasca implementasi dan evaluasi yang semuanya berdampak terhadap terciptanya universitas kelas dunia.
\end{abstract}

\footnotetext{
${ }^{1}$ Faculty of Economics and Business, Universitas Pancasila, Jakarta-Indonesia Email: andiamri43@gmail.com

2 Faculty of Psychology, UIN Sunan Gunung Djati Bandung, Bandung-Indonesia

Email: zulmiramdani@uinsgd.ac.id

3 Universitas Terbuka Jakarta, Jakarta-Indonesia

Email: jaka.warsihan@ecampus.ut.ac.id

4 Universitas Timor, Kefamenanu-Indonesia

Email: lidwinafelisima@unimor.ac.id

Vol.13 (1) June, 2021

Received: February 11, 2021; Received in revised form: March 8, 2021; Accepted: March 9, 2021; Available online: March 30,2021

This is an open access article under a Creative Commons Attribution-NonCommercial-ShareAlike 4.0 International License
} 


\section{INTRODUCTION}

Indonesia is a country which has high variations of ethnicities, languages, cultures, and community dynamics. Each region exists as a distinctive region and makes Indonesia a tolerant nation which in turn gives advantages in life. Each part has various traditions that differentiate it from the other areas (Bunawardi et al., 2016; Sholihah \& Heath, 2016). This tradition is commonly referred to as local wisdom. Local wisdom is a historical treasure and valuable inheritance from the ancestors (Koentjaraningrat, 2009).

However, much of the local wisdom in Indonesia has faded. It is not even implemented anymore due to the change of the time and the increasingly advanced human mindset that has removed the old social institutions' meaning (Hidayati, 2016; Saihu, 2019). In preserving the essence of social institutions from local wisdom in Indonesia, it is necessary to create new institutions which mutually agreed upon and recognized to create, build, and maintain the local wisdom perspectives. One of the solutions that can be applied in the Indonesian education system, especially in implementing a World Class University is by exploring and developing the potential of local wisdom in Indonesia.

World Class University, in general, is defined as the universities that have good rankings recognized internationally (Yeravdekar \& Tiwari, 2014). Other criteria explain that World Class University owns 40 percent of teaching staff with a Ph.D. degree in which every team publishes two international papers per year. Moreover, World Class University must have the number of graduate students 40 percent of the total student population (student body). A minimum research budget must reach US \$ 1300 per staff per year, the number of international students must make up 20 percent, and in terms of Information Communication Technology (ICT), it must provide 10 Kilo Bytes per student (Deem et al., 2008). Therefore, it can be concluded that the use of resources, technology-based management and facilities will also determine the world-class university.

Levin et al. (2006) made several indicators of the World-Class University as follows: 1) excellence in research, 2) academic freedom and an atmosphere of intellectual joy, 3) strong selfmanagement, 4) adequate facilities and funding, including collaborating with international institutions, 5) diversity, 6) internationalization, 7) democratic leadership, 8) gifted students, 9) the use of Information and Communication Technology, 10) quality of learning in lectures, 11) connection with the community or community needs, and 12) internal campus collaboration. These are the 12 indicators obtained from various opinions of campus managers, researchers, and education writers that have been compiled previously.

A World-Class University based on local wisdom is a good idea in preserving existing local knowledge. Furthermore, World Class University is one of Indonesian government's main goals to be achieved (Tilaar, 2008). This policy was set by the government so that Indonesian universities can compete with world-class campuses and at the same time produce graduates who can also compete with graduates from developed countries in the international world (Sala-i-Martín et al., 2012). Thus, the collaboration between media technology, human resources, and local wisdom principles is needed to achieve these goals (Anwas et al., 2018; Warsihna et al., 2019; Warsihna \& Ramdani, 2020).

Among many local pearls of wisdom in Indonesia is the local wisdom in the province of West Sumatra. West Sumatra has a lot of local wisdom and some of them are pretty unique, and only a handful of countries have the same local wisdom as in West Sumatra. An example of this is the system of Tungku Tigo Sajarangan, Tali Tigo Sapilin. The use of the principle of local wisdom is undoubtedly expected to improve the higher education system's quality and to develop the individual character (Anwas, 2011; Ramdani et al., 2019).

The system of Tungku Tigo Sajarangan is a unit of the leadership of Niniak Mamak (customs), Alim Ulama (religion), and Cerdik Pandai (science/government). These three leadership forms were 
born and existed, inseparable from the Minangkabau people's historical journey. The three leadership forms have different statuses, especially their status in society (Gani, 2002). The system of Tungku Tigo Sajarangan, Tali Tigo Sapilin is also a philosophy in the leadership of the Minangkabau community (Gani, 2010; Gani, 2002). These three elements are the symbols of leadership that give colour and influence on the Minangkabau community's development. In the stratification, it isn't easy to distinguish between the three leadership styles because the three leadership styles can be found in a person. Many Niniak Mamak nowadays are also clever and take the religious scholar's role in solving the problems. Thus, various elements in society must be able to see it thoroughly. "Jarangan", basically stands alone, is not mixed up, and has respective areas or areas of power, but the three are interrelated (Gani, 2010; Gani, 2002). Thus, the furnace is a place to express, discuss, and agree on appropriate idea for the community to become "physical and spiritual food."

Tungku Tigo Sajarangan is very close to the Minangkabau people because this term is used in cooking activities. Traditionally, the cooking utensils used by the Minangkabau people are stoves which are usually made of iron or stone. Three stones or iron formed to resemble this equilateral triangle are a solid base to support various dishes cooked on them (Gani, 2010; Gani, 2002). Besides, firewood's flames will be crossed through these three doors while waiting for it to become a good flame. The firewood that crosses each other in the stove is a picture of the differences of opinion that are deliberated together to produce the final decision. The furnace is the analogy of the three leadership elements above, while wood is an idea, opinion, and the flame is a medium for discussion. The pot whose contents have been cooked is the result of a consensus decision (Suarman, 2002). This explanation explains that the cultural manifestations originating from our ancestors' habits can be a basic philosophy as a human study in behaviour today.

Various studies in Indonesia often carry out the use of culture-based local principles in the realm of education. Research conducted by Purwanto and Titasari (2020) has tried to trace religious activities in a remote area and then took these activities' essence into a perspective that many people can accept. Other activities were also carried out by (Ardhyantama, 2020) who also took the concept of Ki Hajar Dewantara learning model as a principle of local wisdom in providing a framework of thinking about good learning. As for the study of local wisdom in supporting the world-class university, not many researchers have done it. Most previous studies focused more on developing local wisdom in primary and secondary schools and some informal education contexts (Amirin, 2013; Desfandi, 2014; Shufa, 2018). Some studies only focus on other aspects of Minangkabau culture, such as food and how people speech, but no one has tried to translate from philosophies related to cultural concepts in education.

Based on the background described above, the researchers offered an empowerment system by interpreting philosophical values with the title: Tungku Tigo Sajarangan, Tali Tigo Sapilin: A Strategy towards World Class University Based on the Local Wisdom. Because so far, there has been no effort to combine the existing government system in West Sumatra to implement the world-class universities.

\section{METHODS}

The research method used in this scientific research study was a qualitative approach. This research was conducted for 3-5 months in the middle of 2020. Qualitative research relates to how the researchers try to understand individuals or groups who experience certain phenomena by using exploratory scientific methods to produce temporary findings and develop an understanding of humans, places, and certain groups (Demuth \& Mey, 2015).

The researchers used several methods to collect data, including interviews, observation, documentation, and audio-visual information (Creswell, 2015; Ivankova et al., 2006; Tashakkori \& 
Creswell, 2007). The researchers obtained raw data in descriptions or descriptions of the sentences to be analyzed using these various methods. The analysis technique used was thematic content analysis, in which the researchers categorized the data by identifying any information obtained in the field. These results were objectified to get categories that will be explained in detail in the discussion section.

The interviews were conducted with two experts in the field of Minangkabau history, culture, and education. The two experts were senior lecturers at Andalas University and Padang State University. Researchers used several general questions related to the topic of study by exploring the sources' opinions. Some examples of indicators used were (1) the urgency of culture in education, (2) the challenges faced in this era, and (3) how the culture and technology can be combined to form an institutional foundation. The observations were carried out in Padang City, West Sumatra province, for one month. The documentation was collected through literature studies, journals, and audiovisual information, namely recorded interviews. The research design in this study can be seen in Figure 1.
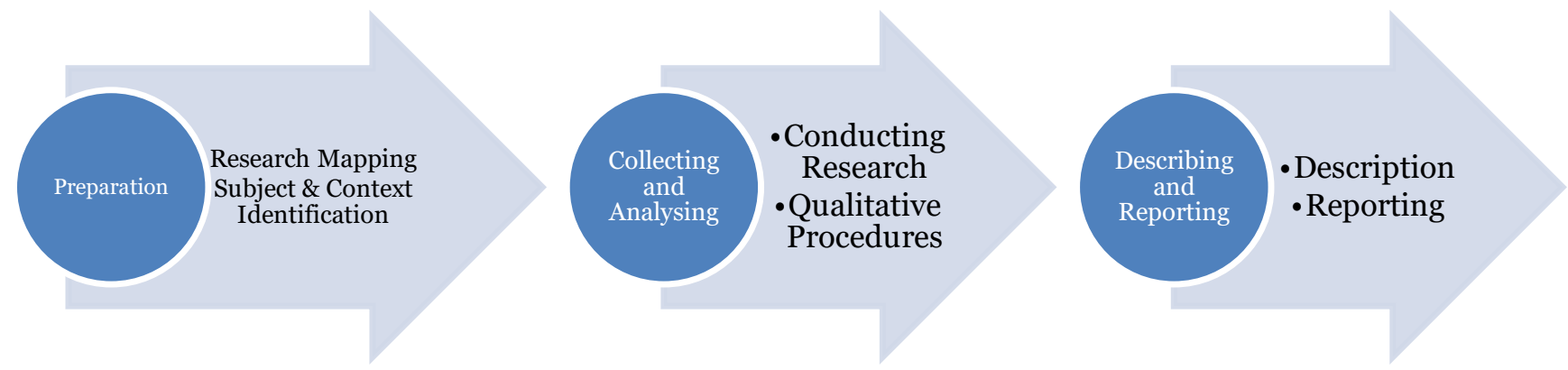

Figure 1. Research Design

\section{FINDINGS AND DISCUSSION}

\section{The concept of Tigo Tungku Sajarangan, Tali Tigo Sapilin}

The core concept of Tigo Tungku Sajarangan, Tali Tigo Sapilin, refers to the leadership elements of Niniak Mamak, Alim Ulama and Cadiak Pandai. According to Muzzami (2004), the characteristics that Niniak Mamak must have are siddiq (correct), tabligh (convey), amanah (trustworthiness), fathonah (knowledgeable and intelligent), and finally wise wisdom. Meanwhile, religious scholars must apply "Adat Basandi Syarak, Syarak Basandi Kitabullah" which is the basis for the Minangkabau people's lives. Alim Ulama takes the role of the builders of faith and morals for the village's children. Meanwhile, Cadiak Pandai has broad knowledge, mastering knowledge, indigenous knowledge, religious knowledge, and science. The meaning and philosophy of Tungku Tigo Sajarangan, Tali Tigo Sapilin can be applied in the World Class University, namely:

a. The Leadership of Niniak Mamak

In Niniak Mamak leadership, it implies that Niniak Mamak must possess some qualities, namely siddiq (correct), tabligh (conveying), amanah (trustworthiness), fathonah (knowledgeable and intelligent), and also wise wisdom. All of these characteristics are applied in Minangkabau customs, while also can be implemented in the world-class universities whereas all of the higher education elements should be applicable. These characteristics are related to being honest in admitting new students, conveying information thoroughly so that all elements within the campus know the information described, having a mutual trust between all elements whether on campus or outside the campus, and finally having knowledge under global rules to produce students who are smart and have a wise attitude in dealing with problems in the campus.

b. The Leadership of Alim Ulama 
The implied philosophical meaning of Alim Ulama which can be implemented in realizing the world-class university is that every university must consider religion, an aspect that should be applied in their respective religious teachings. For example, in requiring Muslim students to dress under Islamic spiritual teachings and following scientific mentoring about the Qur'an and hadith.

c. The Cerdik Pandai Leadership

Cerdik Pandai Leadership's philosophy and its relation to world-class universities are very close to realizing the best educational foundations. Suppose the universities want to be widely known throughout the world. In that case, the essential parties in the campus must have accurate ideas in making rules such as the regulations to bring the universities to become the world-class university with high knowledge.

So the point is that the leadership philosophy of Tigo Tunggu Sajarangan, Tali Tigo Sapilin has social, ethical values which have initially been traditional. This tradition is naturally blended with the influence of modernization, manifested in higher education institutions. Besides, the importance of equality in Minangkabau culture is not based on the philosophy of extreme liberalism in which the local culture upholds the ethics in social relations. Respect for the (rights) of others, as part of democratic values, is reflected in the expression nan ketek dilindungi, nan tuo dihormati, nan samo gadang dipatenggangkan (the smallest is protected, the greatest is respected, the same level is respected). Of course, in this condition, the fundamental values are still maintained. That is why the origin (epistemological elements) and characteristics of Tungku Tigo Sajarangan (ontology) are the most essential parts to be understood. Thus, even though the flow of modernization and globalization constantly hit West Sumatra, in the implementation, it is still based on the provisions of customs and to the sublime values of the traditional adat basandi syarak, syarak basandi Kitabullah, which can be realized, one of which is in the World Class University.

\section{The Steps to Implement Tigo Tungku Sajarangan, Tali Tigo Sapilin}

Before Tigo Tungku Sajarangan, Tali Tigo Sapilin was implemented, there were 12 indicators (Levin et al., 2006) in implementing a world-class university associated with Tungku Tigo Sajarangan, Tali Tigo Sapilin, namely:

a. The excellence of the research. This indicator was reflected in the characteristics of Cadiak Pandai. Cadiak Pandai must master all of the knowledge and use reasons to solve the problems besides having the skills. Likewise, the world-class universities must be able to produce good research quality with good knowledge and skills through the research groups of the lecturers, student research group, and a group that could give the special coaching for student affairs in the context of developing the hard skills, the soft skills and entrepreneurship through student activity units (UKM). Through these activities, it is hoped that the students can compete at the national research level and even at the international level.

b. Academic freedom and an atmosphere of intellectual joy. This indicator is reflected in the three leaders in West Sumatra, namely Niniak Mamak, religious scholars (Alim Ulama), and Cadiak Pandai. It is believed that in expressing something, the three leaders are given the freedom with appropriate and intellectual reasons, then the results are determined by deliberation and consensus. As for the relationship with the world of higher education, all higher education elements must be given freedom in expressing opinions without being covered up, meaning that it is transparent and consensus. For example, in terms of determining the rules for lecturers, employees, and students that must be made in an open forum and providing vast opportunities for lecturers to be able to develop their competencies. Besides, the campus needs to build a good academic culture, including organizing exciting and valuable learning for all elements.

c. Strong self-management (self-management). This indicator is more general in Tigo Tungku Sajarangan, Tali Tigo Sapilin, in which there is the existence of a democratization process in 
management and regulation. The implementation in the world-class universities can be applied through re-arranging the entire student admission (selection) system, the involvement, and participation of all elements of higher education in thinking about the best things for the betterment of the university with management seminars, through student organizations, or through selecting the best study program in self-management.

d. The Adequate facilities and funding, including collaboration with international institutions. Even though it was not directly stated in the Tigo Tungku Sajarangan, Tali Tigo Sapilin, implicitly, the three leaders in Minangkabau always invited Nagari residents to mutually work together to meet the common needs, such as in the construction of the hall of the Kerapatan Adat Nagari (KAN) wherein the construction of this hall, the tools and materials are obtained independently, and even in collaboration with other Nagari. Likewise, the universities must fulfill the facilities independently, such as requiring each scholarship recipient to donate $10 \%$ of the scholarships they receive; requiring the chancellor, lecturers, and employees to set aside 15\% of their salary to meet university facilities. If not fulfilled, they can ask for the government assistance or make a partnership with international institutions.

e. Accepting diversity. It means that universities must accept students from various regions and countries, including in terms of knowledge. It is reflected in the leadership attitude in Minangkabau on being open and taking renewal, with the initial concept of democratization. The implementation is through large-scale promotions in various regions of Indonesia and abroad to get diverse and intelligent students, accompanied by scholarships for regional children, domestic and foreign lecturer exchanges, and student exchanges.

f. Internationalization. It provides many programs such as student exchanges or international students' entry, internationalization of the curriculum, global connections with other institutions (campuses and worldwide companies) to establish the world-class programs. This indicator is quite clear that the three leaders in West Sumatra are also trying to expand the network in various ways. It can be seen from the presence of the Minangkabau tribe in Nagari Sembilan, Malaysia. It means that leadership in Minangkabau is very complex. This objective could be implemented by providing exceptional training in foreign languages and increasing university accreditation.

g. Democratic leadership, namely through open competition between faculties and students and collaboration with external constituents. It is almost the same as before that the world of democratization has never been separated from this system. Still, its application in higher education can be through a rector's election which involving all lecturers, employees, and students.

h. Talented students. The implementation is selecting outstanding students in the class level, study program, faculty, university, or national or international level. It means that all students will try to get at each level.

i. The Use of Information and Communication Technology (ICT). The implementation uses of $L C D$ in the learning process, sending the assignments via social networks, and online tutorials.

j. The quality of learning in lectures. The performance is by replacing the directive learning pattern with non-directive. The lecturers could bring students to learn in the real world of work, invite guest speakers, and do internships.

k. Connection with community or community needs. It could be done by conducting the field survey regarding the university's advantages and disadvantages, community empowerment programs, community service, and social service work.

l. Internal campus collaboration. It could be applied through the discussion and tutorials.

If the indicators number 1 until 7 (excellence in research, academic freedom and an atmosphere of intellectual joy, strong self-management, adequate facilities and funding, including collaborating with international institutions, diversity, internationalization, and democratic 
leadership) have been realized, then the indicators number 8 until 12 (gifted students, the use of Information and Communication Technology, quality of learning in lectures, connection with the community or community needs, and internal campus collaboration) will also automatically be realized. This means that gifted students will be born, technological progress is met along with the quality of learning, and surely there will be a connection with the community due to the collaboration. It means that the leadership system of Tungku Tigo Sajarangan, Tali Tigo Sapilin, has a deep philosophical meaning if it is researched scientifically.

The results of the author's analysis in this study certainly provide fairly clear information regarding the factors that a campus must own to become a credible university. Other studies also supported the research related to curriculum, climate, and learning activities based on projects and technology to be directly applied to the global context (Yang \& Welch, 2012). Besides, all parties' roles were also very supportive of creating world-class universities (Cremonini et al., 2014; Shin \& Kehm, 2013; Shin, 2012). This study is different from other studies because it can emphasize the philosophical roots of regional culture as the right indicator of making a policy.

\section{Stages of Tigo Tungku Sajarangan, Tali Tigo Sapilin Implementation}

\section{a. Preparation}

The steps implemented in this preparation include: 1) Coordinating with local universities on the importance of Tigo Tungku Sajarangan, Tali Tigo Sapilin in realizing a world-class university based on local wisdom of West Sumatra province. 2) Coordinating and collaborating with the government, both central and local governments, in supporting Tigo Tungku Sajarangan, Tali Tigo Sapilin based on Minangkabau local wisdom to realize a world-class university.

b. Implementation

This program is implemented through 3 activities: 1) The Development of Innovative Creativity; 2) Realizing the system in the form of regulations and work programs that will be carried out by all elements of higher education and 3) Improving the quality of educational processes and outcomes that lead to the whole, an integrated and balanced world-class university under established standards.

c. Post Implementation

It means that we will see whether this empowerment system can be continued after the preparation and implementation. This can be seen from various aspects, namely: firstly, we can make a questionnaire in two versions (online media and printed media) where the questionnaire contains questions about the post-implementation of the empowerment system that must be answered by all higher education elements, from the students to the head of the university. Secondly, looking at the achievement index that has been achieved in higher education, such as how many lecturers have received scholarships for further study abroad, producing graduates who are qualified and capable of empowerment. Thirdly, whether the quality and quantity of the empowerment system can be accounted for by the benefits that have been generated or not.

d. Evaluation

Evaluation is a stage to assess or evaluate the success of the empowerment system. Suppose the system is not under the expected target, then it is necessary to innovate improvements that can be carried out to implement a better empowerment system and obtain maximum output in the future. If it is successful then this system will be implemented further by the higher education policies and cooperate with the government to implement the World Class University by improving it to make it better. 


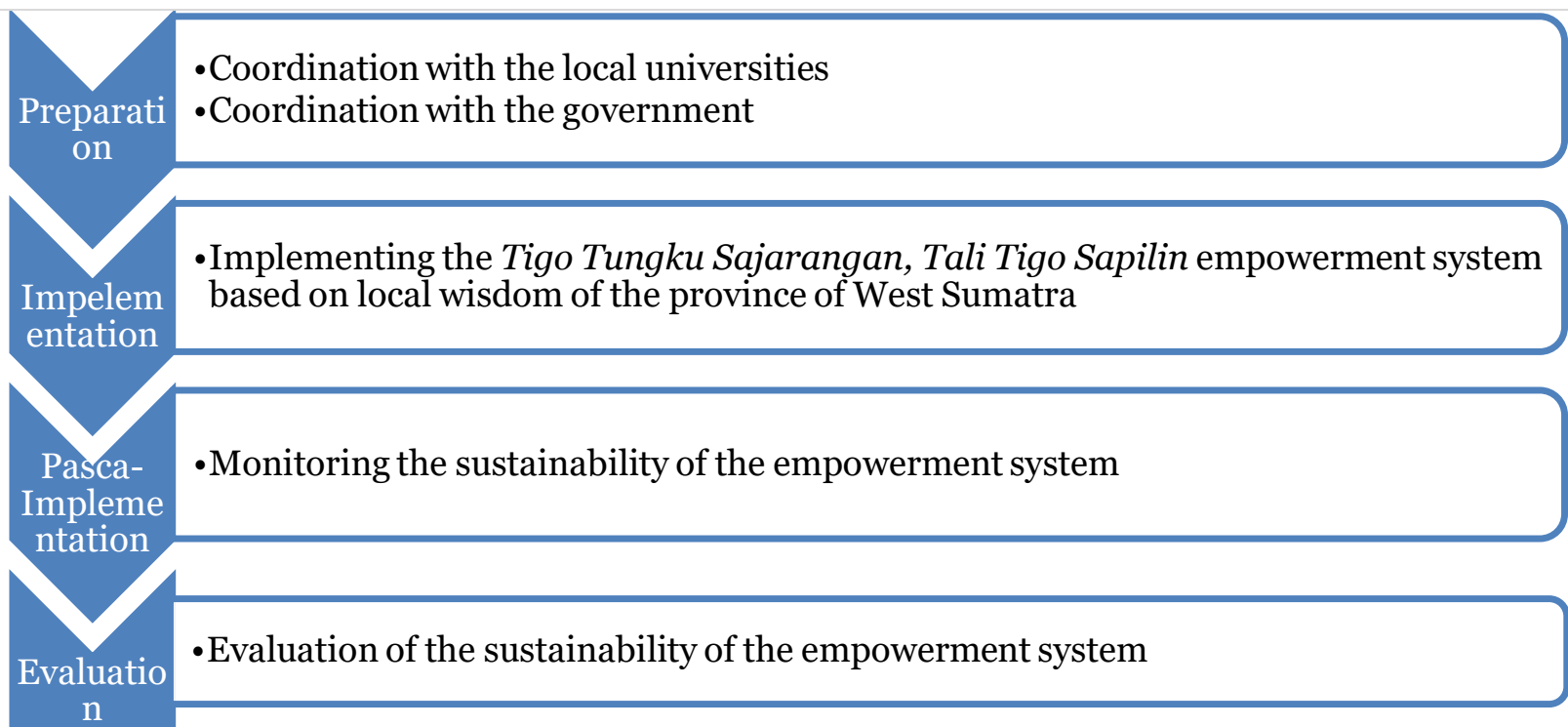

Figure 2. The step of implementation

\section{The Implication of Tigo Tungku Sajarangan, Tali Tigo Sapilin}

The implications of implementing Tigo Tungku Sajarangan, Tali Tigo Sapilin system includes: 1) becoming an international standard university that is popular in the community and has superiority in science, technology and art based on local wisdom in West Sumatra, 2), increasing motivation among elements of higher education institutions to implement the World Class University, 3) Building the network connections nationally or internationally in various aspects, such giving the chance for lecturers and students to continue their studies in higher level and to get a job so that the issue of unemployment is resolved 4) training the ability to think critically and contextually in solving the problems of local wisdom that exist in Indonesia, 5) Preserving the local wisdom, especially in West Sumatra and generally Indonesia, 6) making universities as an agent of change in behaving both at campus and in everyday life, 7) training all elements in the university so that there is an accordance with the government regulation especially the education which relies heavily on character and integrity, 8) training all elements of higher education to be creative and innovate with the aspects that already exist into something valuable.

\section{CONCLUSION}

Tigo Tungku Sajarangan, Tali Tigo Sapilin is a Minangkabau leadership concept where Niniak mamak, Alim Ulama, and Cadiak Pandai have deep meaning and philosophy in implementing the world-class civic university. The importance and philosophy of Tigo Tungku Sajarangan, Tali Tigo Sapilin refers to the provisions of customs, to the sublime value of the adat basandi syarak, syarak basandi Kitabullah (ABS SBK) and is associated with 12 indicators that can be realized, one of which is in the world-class university. Tigo Tungku Sajarangan, Tali Tigo Sapilin is an empowerment system that is relatively new to higher education. Tigo Tungku Sajarangan, Tali Tigo Sapilin is one of the local wisdom that needs to be preserved. The steps for implementing Tigo Tungku Sajarangan, Tali Tigo Sapilin include four stages: preparation, implementation, postimplementation, and evaluation, which have implications for realizing a world-class university.

This study certainly provides a comprehensive picture to the readers that philosophies that come from culture can be the basis for us to make a policy. Meanwhile, in the future, the results of this research will be objectified through a series of experimental activities that show the truth of this philosophy. Of course, through a quantitative approach and trying to see the side of the difference with other cultures besides Minangkabau. 


\section{REFERENCES}

Amirin, T. M. (2013). Implementasi pendekatan pendidikan multikultural kontekstual berbasis kearifan lokal di Indonesia. Jurnal Pembangunan Pendidikan: Fondasi Dan Aplikasi, 1(1). https://doi.org/10.21831/jppfa.v1i1.1047

Anwas, O. M. (2011). Membangun media massa publik dalam menanamkan pendidikan karakter. Jurnal Pendidikan Dan Kebudayaan, 17(6), 680. https://doi.org/10.24832/jpnk.v17i6.59

Anwas, O. M., Steviano, I., \& Warsihna, J. (2018). The use of internet content with interest in learning english on high schools students. The Turkish Online Journal of Educational Technology, 2, 832-836.

Ardhyantama, V. (2020). Pengembangan kreativitas berdasarkan gagasan ki hajar dewantara. Jurnal Pendidikan Dan Kebudayaan, 5(1), 73-86.

Bunawardi, R. S., Suzuki, Y., \& Hiroki, Y. (2016). Utilization driven diversity of public space in rusunawa Makassar, Indonesia. Procedia - Social and Behavioral Sciences, 227 (November 2015), 325-333. https://doi.org/10.1016/j.sbspro.2016.06.078

Cremonini, L., Westerheijden, D. F., Benneworth, P., \& Dauncey, H. (2014). In the shadow of celebrity? World-class university policies and public value in higher education. Higher Education Policy, 27(3), 341-361. https://doi.org/10.1057/hep.2013.33

Creswell, J. (2015). Riset Pendidikan (5th ed.). Penerbit Pustaka Belajar.

Deem, R., Mok, K. H., \& Lucas, L. (2008). Transforming higher education in whose image? Exploring the concept of the "world-class" university in Europe and Asia. Higher Education Policy, 21(1), 83-97. https://doi.org/10.1057/palgrave.hep.8300179

Demuth, C., \& Mey, G. (2015). Qualitative methodology in developmental psychology. International Encyclopedia of the Social \& Behavioral Sciences: Second Edition, 19, 668-675. https://doi.org/10.1016/B978-0-08-097086-8.23156-5

Desfandi, M. (2014). Urgensi kurikulum pendidikan kebencanaan berbasis kearifan lokal di indonesia [The urgency of disaster education curriculum based on local wisdom in Indonesia\}. Sosio Didaktika Sosial Science Education Journal, 1(2), 191-198.

Gani, E. (2010). Pantun minangkabau dalam perspektif budaya dan pendidikan. UNP Press.

Gani, R. (2002). Tungku tigo sajarangan: Analisis model komunikasi kelompok dalam interaksi pemimpin pemerintahan di Sumatera Barat. Universitas Andalas: Skripsi Fakultas Ilmu Budaya.

Hidayati, D. (2016). Memudarnya nilai kearifan lokal masyarakat...| deny hidayati memudarnya nilai kearifan lokal masyarakat dalam pengelolaan sumber daya air (waning value of local wisdom in the management of water resources). Jurnal Kependudukan Indonesia |, 11(Juni), 39-48.

Ivankova, N. V., Creswell, J. W., \& Stick, S. L. (2006). Using mixed-methods sequential explanatory design: From theory to practice. Field Methods, 18(1), 3-20. https://doi.org/10.1177/1525822X05282260

Koentjaraningrat. (2009). Pengantar ilmu antropologi. PT Rineka Citra.

Levin, H. M., Jeong, D. W., \& Ou, D. (2006). What is a world class university. Conference of the Comparative and International Education Society, 1-49.

Muzzami. (2004). Budaya Alam Minangkabau untuk SMP Kelas 1. Bumi Aksara.

Purwanto, H., \& Titasari, C. P. (2020). Mandala kadewaguruan: tempat pendidikan keagamaan di lereng barat gunung lawu abad xiv - xv masehi mandala. Jurnal Pendidikan Dan Kebudayaan, 5(1), 13-42.

Ramdani, Z., Amrullah, S., \& Tae, L. F. (2019). Pentingnya kolaborasi dalam menciptakan sistem pendidikan yang berkualitas. MEDIAPSI, 5(1), 40-48.

Saihu, S. (2019). Pendidikan karakter berbasis kearifan lokal (studi di jembrana bali). Edukasi Islami: Jurnal Pendidikan Islam, 8(01), 69. https://doi.org/10.30868/ei.v8io1.364

Sala-i-Martín, X., Bilbao-Osorio, B., Blanke, J., Crotti, R., Drzeniek-Hanouz, M., Geiger, T., \& Ko, C. (2012). The global competitiveness index 2012 - 2013: strengthening recovery by raising productivity. The Global Competitiveness Report 2012-2013, 3-48. http://tocantinsmais.org.br/mbc/uploads/biblioteca/1386332754.42A.pdf

Shin, J. C., \& Kehm, B. M. (2013). Institutionalization of world-class university in global competition. Institutionalization of World-Class University in Global Competition, 1-301. 
https://doi.org/10.1007/978-94-007-4975-7

Shin, Y. (2012). CEO ethical leadership, Eethical climate, climate ctrength, and collective organizational itizenship behavior. Journal of Business Ethics, 108(3), 299-312. https://doi.org/10.1007/s10551-011-1091-7

Sholihah, A. B., \& Heath, T. (2016). Assessing the quality of traditional street in indonesia: a case study of pasar baru street. Procedia - Social and Behavioral Sciences, 234, 244-254. https://doi.org/10.1016/j.sbspro.2016.10.240

Shufa, Naela, K. F. (2018). Pembelajaran berbasis kearifan lokal di sekolah dasar: sebuah kerangka konseptual. Jurnal Ilmiah Kependidikan, 1(1), 48-53.

Suarman. (2002). Adat minangkabau nan salingka hiduik. Duta Utama.

Tashakkori, A., \& Creswell, J. W. (2007). Editorial: The new era of mixed methods. Journal of Mixed Methods Research, 1(1), 3-7. https://doi.org/10.1177/2345678906293042

Tilaar. (2008). Kekuasaan dan pendidikan manajemen pendidikan nasional dalam pusaran kekuasaan. PT Rineka Citra.

Warsihna, J., \& Ramdani, Z. (2020). Signifikansi kahoot!: Interaksi manusia dan mesin dalam proses pembelajaran. Kwangsan: Jurnal Teknologi Pendidikan, 8(2), 154. https://doi.org/10.3180o/jtp.kw.v8n2.p154--167

Warsihna, J., Ramdani, Z., \& Prakoso, B. H. (2019). Using kahoot to improve students' achievement and critical thinking in undergraduate of psychology students. IADIS International Conference Cognition and Exploratory Learning in Digital Age 2019, 144-150.

Yang, R., \& Welch, A. (2012). A world-class university in China? The case of Tsinghua. Higher Education, 63(5), 645-666. https://doi.org/10.1007/s10734-011-9465-4

Yeravdekar, V. R., \& Tiwari, G. (2014). Global rankings of higher education institutions and india's effective non-presence: why have world-class universities eluded the indian higher education system? And, how worthwhile is the indian government's captivation to launch world class universities. Procedia - Social and Behavioral Sciences, 157, 63-83. https://doi.org/10.1016/j.sbspro.2014.11.010 